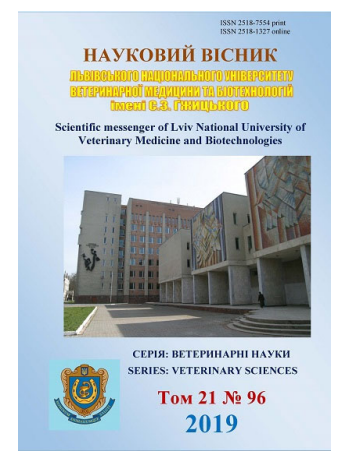

\author{
Науковий вісник Дьвівського національного університету \\ ветеринарної медицини та біотехнологій імені С.3. Гжицького. \\ Серія: Ветеринарні науки
}

\author{
Scientific Messenger of Lviv National University \\ of Veterinary Medicine and Biotechnologies. \\ Series: Veterinary sciences
}

UDC 619:614.48

\title{
Determination of the virucidal properties of the new biocide "DezSan"
}

\author{
O.L. Nechyporenko, A.V. Berezovskyy, T.I. Fotina, R.V. Petrov
}

Sumy National Agrarian University, Sumy, Ukraine

Article info

Received 08.10.2019

Received in revised form 08.11 .2019

Accepted 11.11.2019

Sumy National Agrarian University, G. Kondrat'eva, Str., 160, Sumy, 40000, Ukraine.

Tel.: +38-095-495-29-33

E-mail.: tif_ua@meta.ua
Nechyporenko, O.L., Berezovskyy, A.V., Fotina, T.I., \& Petrov, R.V. (2019). Determination of the virucidal properties of the new biocide "DezSan”. Scientific Messenger of Lviv National University of Veterinary Medicine and Biotechnologies. Series: Veterinary sciences, 21(96), 81-85. doi: $10.32718 /$ nvlvet 9614

The high concentration of farm birds in a limited area creates favorable conditions for the spread of viral diseases. In this regard, the veterinary service is faced with the task of preventing the outbreak of infectious diseases of the poultry and the further spread of the disease. For this purpose a complex of antiepizootic measures is carried out, the key point of which is the disinfection of poultry buildings, equipment, containers, inventory, etc. Industrial poultry is constantly in need of the latest modern disinfectants, which will have the following properties: high biocidal capacity, prolonged action, reduced aggressiveness to treated surfaces, safety for personnel and the environment, ease of use, moderate price. Over time, microorganisms can create resistance to disinfectants. In order to prevent this phenomenon, a permanent rotation of disinfestations at a poultry enterprise, which will be created on the basis of various active substances, is necessary. The goal of the work. Investigate the virilidine action of the new disinfectant "DezSan" for RNA and DNA-containing viruses. Materials and methods of research. To verify the virilidic effect, two series of experiments were carried out using the ducts of hepatitis RNA and the DNA-virus of smallpox of the pox. To determine the effectiveness of the virilidic concentration of "DezSan" in relation to the bird pox virus DNA-content was cultured on chorionic-alantium shell in the 10-12 day chick embryos and to the hepatitis virus duckling virus-RNA-purposive, a suspension of the virulent material that was obtained after propagation virus in primary cultures of dactylon embryo cells. For the experiment, 10 mattresses were used. The virus content of the liquid was mixed with equal volume of disinfectant solution "DezSan", withstand 15, 30 and 60 minutes. In this case, used $0.1 \%, 0.25 \%, 0.5 \%$ and $1 \%$ solution of disinfectant "DezSan". The effectiveness of decontamination of test object surfaces from the pox virus and the hepatitis virus ducts disinfectant was checked in the following order: on a sterilized surface of test objects, a sterile pipette was applied to a suspension of 1 to $2 \mathrm{~cm}^{3}$ of the virus. Contaminated test objects were left in the cuvettes horizontally and vertically, dried for 1-2 hours and with the help of the sprayer, the wetted surface was treated with an experimental disinfectant solution, taking into account the concentration, exposure and amount of disinfectant used. Results of research and discussion. "DezSan" in a concentration of $0.1 \%$ after 15 minutes. Inactivated hepatitis virus ducts by $46.3 \%$; after 30 minutes - by $91.1 \%$, and in an hour - by $94.1 \%$. At $0.25 \%$ concentration of the solution at exposure for 15 minutes. the death of the virus was observed at $99.5 \%$. 30 minutes later and 1 hour - the virus of hepatitis ducklings has been neutralized by $100 \%$. Complete inactivation of the virus in 15 minutes was carried out in the treatment of test surfaces of $0.5 \%$ and $1 \%$ solution "DezSan". In the washings taken after 30 and 60 minutes from surfaces treated with $0.5 \%$ and $1.0 \%$ solution of disinfectant, changes in test systems were not detected. $0.1 \%$ solution of disinfectant "DezSan" after 15 minutes. inactivated viral particles by only $45.7 \%$. 30 minutes later the virus was already eradicated by 93.0\%, and after 1 hour - by 96.0\%. A solution of "DezSan" at a concentration of $0.25 \%$ after 15 min. destroying $99.6 \%$ of viral particles. And after 30 minutes and 1 year completely inactivated the virus. Thus, the experimental means "DezSan" in the concentration of $0.5 \%$ and $1.0 \%$ showed a pronounced virilidine activity and is capable of within 30 and 60 minutes. completely destroy the virus of hepatitis Ducklings. At $0.25 \%$ of the solution "DezSan" after 15 minutes. $99.7 \%$ of the viral parasites of the pox had been disposed of. And after 30 minutes and for 1 hour, the vehicle at the same concentration completely inactivated the virus. It should be noted that in the concentration of $0.5 \%$ and $1.0 \%$, "DezSan" had a pronounced virilidine activity and could completely inactivate the pox virus pox during all controlled periods. Conclusions and prospects for further research. It has been proved that the "DezSan" biocide has expressed virilidic properties in relation to the RNA-containing virus of infectious hepatitis ducts during 
exposure for 15 minutes at concentrations of $0.25 \%$ and above. It was found that $0.25 \%$ solution of disinfectant "Dezsan" at exposures of 30 and more minutes completely kills the DNA - containing pox virus of smallpox. The drug "DezSan" can be used for disinfection measures in poultry farms with viral diseases, as it is effective against RNA and DNA-containing viruses. In future, the sporocidal properties of the biocide "DezSan" will be studied.

Key words: poultry breeding, disinfectant, biocid "DezSan", virucidity, disinfection, viruses.

\title{
Визначення віруліцидних властивостей нового біоциду “ДезСан”
}

\author{
О.Л. Нечипоренко, А.В. Березовський, Т.І. Фотіна, Р.В. Петров \\ Сумський наиіональний аграрний університет, м. Суми, Украӥна
}

В статті наведенні дані дослідження віруліцицних властивостей нового вітчизняного біоциду “ДезСан”. Промислове птахівництво постійно потребує новітніх сучасних дезінфекиійних засобів, які будуть володіти такими властивостями: висока біоцидна здатність, пролонгована дія, знижена агресивність до поверхонь, щзо оброблюються, безпечність для персоналу та навколишнього середовища, простота застосування, помірна иіна. 3 часом у мікроорганізмів можливе утворення резистентності до дезінфікуючих засобів. Щоб запобігти даному явищу необхідна постійна ротація деззасобів на птахівничому підприємстві, шзо будуть створені на основі різних діючих речовин. Дослідження проводили в умовах лабораторії “Ветеринарна фармація” Сумського національного аграрного університету та лабораторї Сумської Державної біологічної фабрики. Для перевірки вірулічидної дї були проведені дві серії дослідів з використанням РНК-вірусу гепатиту каченят та ДНК-вірусу віспи птиці. Визначення ефективності знищення вірусу віспи птиці дезінфектантом проводили методом знезараження тест-об 'єктів і суспензійним методом. Доведено, що біочид “ДезСан” має виражені вірулічидні властивості шодо РНК-вмістного вірусу інфекиійного гепатиту каченят при експозииї 15 хвилин у концентраціях 0,25\% та вище. Встановлено, щзо 0,25\% розчин дезінфектанту “ДезСан” за експозиції 30 та більше хвилин повністю вбиває ДНК-вмісний вірус віспи птииі. Біочид “ДезСан” може бути використаний при проведенні дезінфекційних заходів в птахівничих господарствах при вірусних захворюваннях, оскільки він ефективний щзод РНК та ДНК-вмісних вірусів.

Ключові слова: птахівництво, дезінфектант, біоцид “ДезСан”, віруліциидність, дезінфекція, віруси.

\section{Вступ}

В навколишньому середовищі $є$ велика кількість різних збудників, які здатні викликати захворювання у птиці. При потраплянні в ослаблений або виснажений організм птиці такі мікроорганізми швидко розмножуються, птиця починає хворіти. Небезпечні вони тим, що від хворої особини поступово заражається все поголів'я. Важливо зазначити, що інфекційні хвороби птиці, до яких належать і вірусні, можуть викликати смертність серед птиці до 100\% (Karysheva, 2002; Fotina \& Vashchyk, 2017; Plys, 2018).

Спалахи інфекційних хвороб птахів періодично виникають в різних країнах світу, в тому числі і в Україні. Найбільш небезпечними і поширеними серед вірусних захворювань $\epsilon$ ньюкаслська хвороба, грип, інфекційний бронхіт, інфекційний ларинготрахеїт, хвороба Гамборо (Verzhykhovskyi et al., 2007). Висока концентрація поголів'я сільськогосподарської птиці на обмеженій території створює сприятливі умови для розповсюдження вірусних захворювань (Verbytskyi et al., 2004). У зв'язку з цим перед ветеринарною службою постає завдання не допустити спалаху інфекційних хвороб птиці та подальшого розповсюдження хвороби. Для цього проводиться комплекс протиепізоотичних заходів, ключовим моментом яких є проведення дезінфекції птахівничих приміщень, обладнання, тари, інвентарю тощо (Vengerko, 2007; Kolos et al., 2007).

Промислове птахівництво постійно потребує новітніх сучасних дезінфекційних засобів, які будуть володіти такими властивостями: висока біоцидна здат- ність, пролонгована дія, знижена агресивність до поверхонь, що оброблюються, безпечність для персоналу та навколишнього середовища, простота застосування, помірна ціна (Verbytskyi et al., 2004; Panikar et al., 2006). 3 часом у мікроорганізмів можливе утворення резистентності до дезінфікуючих засобів. Щоб запобігти даному явищу необхідна постійна ротація деззасобів на птахівничому підприємстві, що будуть створені на основі різних діючих речовин (Denyer \& Stewart, 1998).

Мета $і$ завдання дослідження. Дослідити віруліцидну дію нового дезінфікуючого біоциду “ДезСан” щодо РНК та ДНК-вмісних вірусів. Для досягнення поставленої мети необхідно було вирішити такі завдання:

1. Встановити необхідну концентрацію деззасобу для інактивації ДНК та РНК-вмісних вірусів.

2. Визначити експозицію для ефективного знешкодження вірусів.

3. Надати пропозиції щодо використання біоциду “ДезСан” в птахівничих господарствах для проведення дезінфекції.

\section{Матеріал і методи досліджень}

Дослідження проводили в умовах лабораторії “Ветеринарна фармація” Сумського національного аграрного університету та лабораторії Сумської Державної біологічної фабрики. В своїх дослідах ми використали біоцид “ДезСан" виробництва НВФ "Бровафарма". Основні діючі речовини біоциду: алкілдиметилбензиламонію хлорид, октилдецилдиметиламонію хлорид, 
дидецилдиметиламонію хлорид, диоктилдиметиламонію хлорид, глутаровий альдегід.

Для перевірки віруліцидної дії провели дві серії дослідів з використанням РНК-вірусу гепатиту каченят та ДНК- вірусу віспи птиці (Kotsiumbas et al., 2006).

Для визначення ефективності віруліцидної концентрації “ДезСан” щодо вірусу віспи птиці - ДНКвмісний культивували на хоріон-алантоїсній оболонці в 10-12-денних курячих ембріонах та до вірусу гепатиту каченят - РНК-вмісний використовували суспензію вірусовмісного матеріалу, який отримували після розмноження вірусу на первинних культурах клітин качиних ембріонів.

Для досліду використовували по 10 матраців. Вірусомістку рідину змішували з рівним об'ємом розчину дезінфектанту “ДезСан”, витримували по 15, 30 та 60 хв. При цьому використовували $0,1 \%, 0,25 \%$, $0,5 \%$ і $1 \%$ розчини дезінфектанту “ДезСан”. Ефективність знезараження поверхонь тест-об'єктів від вірусу віспи птиці та вірусу гепатиту каченят дезінфектантом перевіряли у такому порядку: на простерилізовану поверхню тест-об'єктів наносили стерильною піпеткою 1-2 см³ суспензії вірусу. Контаміновані тестоб'єкти залишали в кюветах горизонтально і вертикально, підсушували 1-2 години та за допомогою оприскувача зволожували поверхню дослідним дезінфікуючим розчином з урахуванням концентрації, експозиції і кількості використаного дезінфектанту. Як контроль для обробки тест-об'єктів використовували стерильну воду. Через певний час 3 поверхні тестоб'єктів робили змиви стерильною марлевою серветкою з контрольних та дослідних проб. До проби рідини (10-50 см ${ }^{3}$ додавали 0,05 М трис-буфер (рН 9,0), в об'ємі 1-2 см с $^{3}$ струшували протягом 5 хв. Суміш центрифугували при 1500 об/хв 15-20 хв, надосадову рідину використовували для визначення залишкової інерційності. Надосадову рідину та поживне середовище (на основі інактивованої сироватки крові великої рогатої худоби) вносили для визначення цитопатичної дії в моношар культури клітин. Прояв цитопатичної дії (ЦПД) в моношарі культури клітин мав проявлятись у вигляді округлення клітин, утворення симпластів і багатоядерних клітин та появи в них зернистості. Ступінь дегенерації клітин оцінювали за 4-бальною системою у хрестах: ++++ - деструкція всіх клітин (клітини від'єдналися від скла і плавають у середовищі); +++ - поряд 3 повною дегенерацією трапляються окремі живі неушкоджені клітини; ++ деструкція половини клітин; + - дегенерація менше половини клітин. Відсутність дегенерації - клітини культури не відрізняються від контрольної (не зараженої вірусом) культури. Для підтвердження цитопатичного ефекту використовували РН (реакцію нейтралізації).

Отримані результати оброблювали статистично 3 використанням критерію Стьюдента та табличного редактора "Excel".

\section{Результати та їх обговорення}

На першому етапі досліджень була визначена віруліцидна дія біоциду “ДезСан” на вірус гепатиту каченят (РНК-вмісний). Визначення ефективності віруліцидних властивостей “ДезСан” на вірус гепатиту каченят на рівні 15-75 пасажів проводили на первинних культурах клітин качиних ембріонів (табл. 1).

\section{Таблиця 1}

Ефективність інактивації вірусу гепатиту каченят за допомогою дезінфектанту “ДезСан” на поверхні тестоб'єктів, \% (M $\pm \mathrm{m}, \mathrm{n}=10)$

\begin{tabular}{cccc}
\hline Експозиція & \multicolumn{4}{c}{} \\
\cline { 2 - 4 }$($ хв) & 0,1 & 0,25 & 0,5 \\
\hline 15 & $46,3 \pm 0,2$ & $99,5 \pm 0,3 * *$ & 100 \\
30 & $91,1 \pm 1,6$ & 100 & 1,0 \\
60 & $94,1 \pm 0,4 *$ & 100 & 100 \\
100 & 100 \\
\hline
\end{tabular}

Примітка: *-P $<0,05, * *-\mathrm{P}<0,01$

Ефективність знешкодження вірусу гепатиту каченят розчинами “ДезСан” проводили суспензійним методом знезараження тест-об'єктів. Під час проведення досліджень була доведена ефективність дезінфектанту на вірус, що був на поверхні тест-об'єктів, змін в культурі клітин не виявлено. Виходячи 3 результатів табл. 1 можна стверджувати, що “ДезСан” в концентрації 0,1\% через 15 хв інактивував вірус гепатиту каченят на $46,3 \%$; через 30 хв - на $91,1 \%$, а через годину - на 94,1\%.

При 0,25\% концентрації розчину при експозиції 15 хв загибель вірусу спостерігали на 99,5\%.
Через 30 хв і 1год - вірус гепатиту каченят був знешкоджений на $100 \%$.

Повна інактивація вірусу через 15 хвилин здійснювалась при обробці тестових поверхонь 0,5\% і 1\% розчином “ДезСан”. В змивах, які були взяті через 30 та 60 хвилин $з$ поверхонь, оброблених 0,5\% і 1,0\% розчином дезінфектанту, змін у тест-системах не виявляли.

Віруліцидну концентрацію “ДезСану” для інактивації вірусу гепатиту каченят визначали суспензійним методом, згідно 3 існуючою методикою, як тестсистеми клітин качиних ембріонів, в яких відбувалось розмноження вірусу гепатиту каченят (табл. 2). 
Таблиця 2

Інактивація вірусу гепатиту каченят розчинами дезінфектанту (суспензійний метод) “ДезСан” $(\mathrm{M} \pm \mathrm{m}, \mathrm{n}=10)$

\begin{tabular}{ccccc}
\hline Експозиція, & \multicolumn{4}{c}{ Концентрація “ДезСан”, \% } \\
\cline { 2 - 5 } хв & 0,1 & 0,25 & 0,5 & 1 \\
\hline \multirow{2}{*}{15} & $\underline{10^{9,30 \pm 0,18}}$ & $\underline{10^{6,8 \pm 0,53}}$ & $\underline{0}$ & $\underline{0}$ \\
& $45,7 \pm 0,4^{*}$ & $99,6 \pm 0,4^{* *}$ & $\underline{0}$ & 100 \\
30 & $\underline{10^{8,6 \pm 0,62}}$ & $\underline{0}$ & 100 & 100 \\
& $93,0 \pm 0,4^{* *}$ & $\underline{0}$ & $\underline{0}$ & $\underline{0}$ \\
\hline
\end{tabular}

Примітка: *- $\mathrm{P}<0,05, * *-\mathrm{P}<0,01$

Вихідний титр вірусу гепатиту каченят $10^{9,3} \mathrm{EiД}_{50} / \mathrm{cm}^{3} ;$ В чисельнику вказана залишкова інфекиійність вірусу в $\mathrm{lg}$ ЕіД В знаменнику - ефективність інактивачії вірусу, \%.

Виходячи з даних табл. 2, бачимо, що 0,1\% розчин дезінфектанту “ДезСан” через 15 хв інактивував вірусні частинки лише на 45,7\%. Через 30 хв знешкодження вірусу відбувалося уже на 93,0\%, а через 1 год. - на 96,0\%.

Розчин “ДезСану” у концентрації 0,25\% через 15 хв знищував 99,6\% вірусних частинок. А через 30 хв та 1 год повністю інактивував вірус.

Таким чином, експериментальний засіб “ДезСан” в концентрації 0,5\% і 1,0\% виявив виражену віруліцидну активність і здатний протягом 30 і 60 хв повністю знищити вірус гепатиту каченят.

Таблиця 3

Показники ефективності інактивації вірусу віспи птиці за допомогою дезінфектанту “ДезСан” на поверхні тестоб'єктів $(\mathrm{M} \pm \mathrm{m}, \mathrm{n}=10)$

\begin{tabular}{|c|c|c|c|c|}
\hline \multirow{2}{*}{$\begin{array}{c}\text { Експозиція } \\
\text { (хв) }\end{array}$} & \multicolumn{4}{|c|}{ Концентрація дезінфектанту, \% } \\
\hline & 0,1 & 0,25 & 0,5 & 1,0 \\
\hline 15 & $45,4 \% \pm 0,2$ & $98,3 \% \pm 0,2 *$ & $100 \%$ & $100 \%$ \\
\hline 30 & $90,7 \% \pm 1,4$ & $100 \%$ & $100 \%$ & $100 \%$ \\
\hline 60 & $95,1 \% \pm 0,5 *$ & $100 \%$ & $100 \%$ & $100 \%$ \\
\hline
\end{tabular}

Примітка: *-P <0,05

3 даних табл. 3. видно, що “ДезСан” в 0,1\% концентрації через 15 хв інактивував вірус лише на 45,4\%. Проте через 30 хв ефективність дезінфектанту зросла до 90,7\%, а через 1 годину - до 95,1\%. При обробці тест-об'єктів 0,25\% розчином “ДезСан” через 15 хв спостерігали загибель вірусу на 98,3\%, а через 30 хв і 1 годину - вірус віспи птиці знешкоджений на 100\%. При обробці поверхонь $0,5 \%$ і $1 \%$ розчином “ДезСану” вже через 15 хв відбувалась повна інактивація вірусу. У змивах, з оброблених $0,5 \%$ та $1 \%$ розчинами поверхонь, які були взяті через 30 хв и 1 год, змін у тест-системах (хоріон-алантоїсні оболонки в 10-12-денних курячих ембріонах) не виявлено.

При проведенні досліджень суспензійним методом ставили за мету визначити ефективну віруліцидну концентрацію дезінфікуючого засобу "ДезСан" для інактивації вірусу віспи птиці. В дослідженнях визначали віруцидну активність таких концентрацій дезін-
На другому етапі досліджень визначали віруцидну дію експериментального засобу “ДезСан” на вірус віспи птиці (ДНК-вмісний).

3 метою визначення ефективної віруліцидної концентрації “ДезСан” щодо ДНК-вмісного вірусу віспи птиці культивували його на хоріон-алантоїсній оболонці в 10-12-денних курячих ембріонах. Визначення ефективності знищення вірусу віспи птиці дезінфектантом проводили методом знезараження тестоб'єктів і суспензійним методом згідно з рекомендаціями. Варто зазначити, що в результаті проведених досліджень змін в культурі клітин не виявлено. Це свідчить про ефективність дезінфекційного засобу на вірус, який містився на поверхні тест-об'єкту (табл. 3). 


\section{Таблищя 4}

Інактивація вірусу віспи птиці за дії дезінфектанту (суспензійний метод) “ДезСан” (M \pm m, n = 10)

\begin{tabular}{|c|c|c|c|c|}
\hline \multirow{2}{*}{$\begin{array}{c}\text { Експозиція } \\
\text { (хв.) } \\
\end{array}$} & \multicolumn{4}{|c|}{ Концентрація “ДезСан”, \% } \\
\hline & 0,1 & 0,25 & 0,5 & 1 \\
\hline \multirow{2}{*}{15} & $10^{9,25 \pm 0,15}$ & $10^{5,8 \pm 0,45}$ & $\underline{0}$ & $\underline{0}$ \\
\hline & $\overline{44,3 \pm 0,4^{*}}$ & $99,7 \pm 0,6^{*}$ & 100 & 100 \\
\hline \multirow{2}{*}{30} & $\underline{10^{8,56 \pm 0,39}}$ & $\underline{0}$ & $\underline{0}$ & $\underline{0}$ \\
\hline & $90,1 \pm 0,4^{*}$ & 100 & $1 \overline{0} 0$ & $1 \overline{0} 0$ \\
\hline \multirow{2}{*}{60} & $10^{6,4 \pm 0,65}$ & $\underline{0}$ & $\underline{0}$ & $\underline{0}$ \\
\hline & $97,1 \pm 0,5 *$ & 100 & 100 & $1 \overline{0} 0$ \\
\hline
\end{tabular}

Примітка: * $-\mathrm{P}<0,05$

Вихідний титр вірусу віспи птищі $10^{9,5} \mathrm{Ei}_{50} / \mathrm{cm}^{3}$;

В чисельнику вказана залишкова інериійність вірусу в $\lg$ EiД50/ $\mathrm{cm}^{3}$;

В знаменнику - ефективність інактивації вірусу, \%.

При аналізі даних, отриманих за двома різними методиками, можна стверджувати, що $0,25 \%$ розчин дезінфектанту “ДезСан” за експозиції 30 та більше хвилин повністю вбиває вірус віспи птиці.

Таким чином, доведено, що біоцид “ДезСан” має виражені віруліцидні властивості щодо РНК- та ДНКвмісних вірусів у концентраціях 0,25\% та вище.

\section{Висновки}

1. Доведено, що біоцид “ДезСан” має виражені віруліцидні властивості щодо РНК-вмісного вірусу інфекційного гепатиту каченят при експозиції 15 хвилин у концентраціях 0,25\% та вище.

2. Встановлено, що $0,25 \%$ розчин дезінфектанту “ДезСан” за експозиції 30 та більше хвилин повністю вбиває ДНК-вірус віспи птиці.

3. Біоцид “ДезСан” може бути використаний при проведенні дезінфекційних заходів в птахівничих господарствах при вірусних захворюваннях, оскільки він ефективний щодо РНК та ДНК-вмісних вірусів.

Перспективи подальших досліджень. В подальшому будуть вивчені спороцидні властивості біоциду "ДезСан".

\section{References}

Denyer, S.P., \& Stewart, G.S.A.B. (1998). Mechanisms of action of disinfectants. Int Biodeter Biodegr, 41(3-4), 261-268. doi: 10.1016/S0964-8305(98)00023-7.

Fotina, T., \& Vashchyk, Y. (2017). Comparative evaluation of effectiveness of preparations "Saroflox" and enrofloxacin towards to the pathogens of poultry's bacterial diseases. Scientific Messenger of LNU of Veterinary Medicine and Biotechnologies. Series:
Veterinary Sciences, 19(77), 143-147. doi: 10.15421/nvlvet7731.

Karysheva, A.F. (2002). Spetsialna epizootolohiia: Pidruchnyk. K.: Vyshcha osvita (in Ukrainian).

Kolos, Yu., Stets, V., \& Tytarenko, V. (2007). Rol sanitarnoi obrobky - dezinfektsii u pidtrymanni stabilnoho epizootychnoho blahopoluchchia $u$ ptakhivnytstvi. Veterynarna medytsyna Ukrainy, 12, 28-30 (in Ukrainian).

Kotsiumbas, I.Ia., Malyk, O.H., \& Patereha, I.P. (2006). Doklinichni doslidzhennia veterynarnykh likarskykh zasobiv. Lviv: Triada plius (in Ukrainian).

Panikar, I.I., Reshetylo, O.I., \& Panikar, I.I. (2006). Vyrobnychi vyprobuvannia novitnikh dezinfektantiv u ptakhivnytstvi. Visnyk Sum. NAU. Sumy, 1-2(1516), 147-149 (in Ukrainian).

Plys, V. (2018). The influence of symbionts of microbiocenosis on the indicators cytohemopoez at mixed pasteurellosis and ascaridosis disease bird. Scientific Messenger of LNU of Veterinary Medicine and Biotechnologies. Series: Veterinary Sciences, 20(83), 25-29. doi: 10.15421/nvlvet8305.

Vengerko, L.A. (2007). Veterinarno-sanitarnye meroprijatija po zashhite pticevodcheskih hozjajstv ot zanosa vozbuditelej zaraznyh boleznej. Efektivne ptahivnictvo. 6(30), 5-8. https:/lib.dsau.dp.ua/ book/37961? lang=ua (in Russian).

Verbytskyi, P.I., Dostoievskyi, P.P., \& Busol, V.O. (2004). Dovidnyk likaria veterynarnoi medytsyny. K.: Urozhai (in Ukrainian).

Verzhykhovskyi, O., Kolos, Yu., Tytarenko, V., \& Stets, V. (2007). Epizootychnyi stan ptakhivnytstva v Ukraini. Vet. medytsyna Ukrainy, 6, 8-10 (in Ukrainian). 